Wilfred John E. Santiañez*, Erasmo C. Macaya, Kyung Min Lee, Ga Youn Cho, Sung Min Boo and Kazuhiro Kogame

\title{
Taxonomic reassessment of the Indo-Pacific Scytosiphonaceae (Phaeophyceae): Hydroclathrus rapanuii sp. nov. and Chnoospora minima from Easter Island, with proposal of Dactylosiphon gen. nov. and Pseudochnoospora gen. nov.
}

https://doi.org/10.1515/bot-2017-0089

Received 25 October, 2017; accepted 15 December, 2017

Abstract: A new and putatively endemic species of Hydroclathrus, Hydroclathrus rapanuii, is described from the geographically isolated Easter Island in the southeastern Pacific based on morphological and molecular phylogenetic data. It is distinguished from other Hydroclathrus by thalli of unevenly furrowed thin membranes, and angular, block-like plurangial sori. Our phylogenetic analyses indicated that $H$. rapanuii is closely related to the generitype Hydroclathrus clathratus. We also report on the morphology and phylogeny of Chnoospora minima from Easter I. and elsewhere in the Indo-Pacific Ocean, noting the previously unreported presence of hollow portions in its medulla. Although not collected from Easter I., we herein propose the recognition of two new genera, Dactylosiphon gen. nov. and Pseudochnoospora gen. nov., based on our three-gene phylogeny and their known morphologies and anatomies. Dactylosiphon is based on the three species currently assigned to Colpomenia (C. bullosa, C. durvillei, and $C$. wynnei) that are genetically and morphologically (i.e. thalli with erect and finger-like tubes arising from a common saccate base) distinct from other members of

\footnotetext{
*Corresponding author: Wilfred John E. Santiañez, Department of Natural History Sciences, Graduate School of Science, Hokkaido University, Sapporo 060-0810, Japan,

e-mail:wjesantianez@gmail.com

Erasmo C. Macaya: Laboratorio de Estudios Algales (ALGALAB), Departamento de Oceanografía, Casilla 160-C, Universidad de Concepción, Concepción, Chile; and Millennium Nucleus: Ecology and Sustainable Management of Oceanic Island (ESMOI), Coquimbo, Chile

Kyung Min Lee: Department of Ecology and Genetics, University of Oulu, Oulu 90014, Finland

Ga Youn Cho: National Institute of Biological Resources, Incheon 22689, South Korea

Sung Min Boo: Department of Biology, Chungnam National University, Daejeon 305-764, South Korea

Kazuhiro Kogame: Department of Biological Sciences, Faculty of

Science, Hokkaido University, Sapporo 060-0810, Japan
}

Colpomenia. The monotypic genus Pseudochnoospora is represented by the decumbent, branching, and interadhesive species currently known as Chnoospora implexa. With the above proposals, we further increase the genus-level diversity of Scytosiphonaceae in the IndoPacific Ocean.

Keywords: Dactylosiphon gen. nov.; Easter Island; Indo-Pacific Ocean; Pseudochnoospora gen. nov.; Scytosiphonaceae.

\section{Introduction}

Easter Island, locally known by its Polynesian name as "Rapa Nui", is a geographically isolated volcanic island located in the South Pacific Ocean. Owing largely to its remoteness, its macroalgal flora has been subjected to several floristic and biogeographical studies (e.g. Børgesen 1924, Santelices and Abbott 1987, Ramírez and Müller 1991, Santelices and Meneses 2000), which has resulted in a present total of 143 recorded species (Fernández et al. 2014). Some $14 \%$ of the species appear to be endemic to the island and, collectively, its flora has an Indo-Pacific affinity (Santelices and Abbott 1987, Ramírez and Müller 1991, Santelices and Meneses 2000). Somewhat unexpectedly, the flora seems to share more common elements with Nha Trang, Vietnam (ca. 16,000 km) than with the relatively near Juan Fernández Archipelago (ca. $3200 \mathrm{~km}$ away) (Santelices and Abbott 1987). The stark differences between the flora of Easter Island and Juan Fernández Archipelago have been attributed to the isolating effects of ocean currents and temperatures that intervene between these localities, especially the cold Humboldt Current (Santelices and Abbott 1987, Santelices and Meneses 2000).

Recent assessment of the diversity of the brown algal genus Hydroclathrus Bory de Saint-Vincent suggested that species diversity is high within the IndoPacific Ocean (Santiañez et al. 2018), with four out of the five currently known species originally described from 
the area. These include Hydroclathrus tenuis Tseng et $\mathrm{Lu}$ from Paracel Islands in the South China Sea (Tseng and Lu 1983), Hydroclathrus stephanosorus Kraft from Lord Howe I., Australia, Hydroclathrus tumulis Kraft et Abbott from Necker I. in the Northwestern Hawaiian Islands, USA (Kraft and Abbott 2003), and the most recently described Hydroclathrus minutus Santiañez et Kogame from Okinawa, Japan (Santiañez et al. 2018). As previous taxonomic studies on Hydroclathrus focused on the northern hemisphere and as pseudo-cryptic species were present in the genus (Santiañez et al. 2018), we extended our work into the southern Pacific, particularly at Easter I., Chile.

With respect to scytosiphonacean algae, Easter I. is geographically important as it represents the southeastern Pacific distribution limit of Chnoospora minima (K. Hering) Papenfuss and is second only to Juan Fernández Archipelago (Etcheverry 1986) as the easternmost distribution limit of the widely distributed Hydroclathrus clathratus (C. Agardh) Howe. As $\mathrm{H}$. clathratus is the default species-designation for perforate sac-like Scytosiphonaceae, and as there is a tendency for new Hydroclathrus species to be discovered at isolated volcanic islands (Kraft and Abbott 2003, Santiañez et al. 2018), we assessed the identity of the purported " $H$. clathratus" at the remote volcanic Easter Island. We herein describe a new and putatively endemic species of Hydroclathrus based on specimens from Vaihu, Easter I. Additionally, we report on the morphology/anatomy and phylogeny of the widely distributed Ch. minima collected from the island.

The genus-level taxonomy in the family Scytosiphonaceae has been problematical due to the unresolved relationships of the different taxa as highlighted in phylogenies based on single and multiple genes (e.g. Kogame et al. 1999, Cho et al. 2006, Kogame et al. 2011, West et al. 2015, McDevit and Saunders 2017, Santiañez et al. 2018). These difficulties have been attributed to the frequently broad taxonomic circumscriptions of the genera, resulting in the assignment of species to genera such as Chnoospora J. Agardh, Colpomenia (Endlicher) Derbès et Solier in Castagne, Hydroclathrus Bory de Saint-Vincent, Petalonia Derbès et Solier, and Scytosiphon C. Agardh despite distinct morpho-anatomical and life history differences from the type species of these genera (Santiañez et al. 2018). Recently, McDevit and Saunders (2017) proposed the recognition of the genus Planosiphon McDevit et Saunders to accommodate species previously assigned to Scytosiphon [S. complanatus (Rosenvingea) Doty, S. gracilis Kogame] and Petalonia [P. zosterifolia (Reinke) Kuntze], which possess flattened, non-constricted blades that are hollow or partially hollow, lack paraphyses among aggregates of uniseriate plurangia, and whose prostrate sporophyte thalli are Compsonema-like and bear only unangia (Santiañez and Kogame 2017). Santiañez et al. (2018) also suggested the possibility of segregating Chnoospora implexa J. Agardh from the genus Chnoospora based on significant morphological and genetic differences. In the light of these recent developments, we have now reviewed the generic circumscriptions within the family and propose several taxonomic revisions. Based on morpho-anatomical, genetic, and life history differences, we propose the removal of the elongate species of Colpomenia [C. bullosa (D.A. Saunders) Yamada, C. durvillei (Bory de SaintVincent) M.E. Ramírez, and C. wynnei K.M. Lee, R. Riosmena-Rodriguez, Kogame et S.M. Boo] to the new genus Dactylosiphon gen. nov. as well as that of Ch. implexa to Pseudochnoospora gen. nov.

\section{Materials and methods}

Samples of Hydroclathrus and Chnoospora were collected by snorkeling in Vaihu and Tahai, Easter I. in March and November 2016 (Table S1). A portion of each sample was dried in silica-gel prior to air-drying as herbarium specimens. Voucher specimens are deposited in the Herbarium, Botany Section, Museo Nacional de Historia Natural, Santiago, Chile (SGO) and the Herbarium of the Faculty of Science, Hokkaido University, Sapporo, Japan (SAP).

For morpho-anatomical analyses, sections were made by hand, stained with $0.5 \%$ aniline blue with phenol, and mounted in 50\% glycerol or 30\% Karo in distilled water on glass slides. A Nikon Digital Sight DS-L1 camera (Tokyo, Japan) mounted on a Nikon Optiphot-2 microscope was used for taking photomicrographs.

For molecular analyses, DNA extraction, PCR, and sequencing of the mitochondrial cox 3 as well as the plastid $r b c \mathrm{~L}$ and $p s a \mathrm{~A}$ genes, including their respective sequencing primers, followed procedures outlined in Santiañez et al. (2018).

Phylogenetic analyses were conducted using individual genes (cox3: $660 \mathrm{bp}, p s a \mathrm{~A}: 1488 \mathrm{bp}$, and rbcL: 1467) and concatenated (cox3: $610 \mathrm{bp}, p s a \mathrm{~A}: 740 \mathrm{bp}$, and rbcL: $1383 \mathrm{bp}=2733 \mathrm{bp}$; partitioned by gene and codon) datasets. Newly generated sequence data were analyzed together with sequences of other scytosiphonacean algae downloaded from GenBank. All trees were rooted with Ectocarpus siliculosus (Dillwyn) Lyngbye, Chordaria flagelliformis (O.F. Müller) C. Agardh, and Pylaiella littoralis (Linnaeus) Kjellman (Table S1). ClustalW in MEGA 
v.6 (Tamura et al. 2013) was used to align sequences. All datasets were analyzed for Maximum Likelihood (ML) and Bayesian Inference (BI); in both cases, GTR $+\mathrm{I}+\Gamma$ model, as selected by Akaike Information Criterion (AIC) in MrModeltest 2.3 (Nylander 2004), was used. ML analyses with 1000 bootstrap pseudoreplicates were conducted using RAxML v.8 (Stamatakis 2014) in the CIPRES Phylogenetic Portal (Miller et al. 2010). BI was conducted in MrBayes v3.2.1 (Huelsenbeck and Ronquist 2001). Markov-chain Monte Carlo iterations were run for 25 million generations until the average standard deviations of split frequencies fell below 0.01 , indicating convergence of the iterations. A burn-in of $25 \%$ was set before calculating the trees.

\section{Results}

\section{Phylogenetic analyses}

Nine samples of scytosiphonacean algae, representing 13 new sequences, were used in this study (Table S1).

Our phylogenetic analyses based on cox3 sequence data recovered all Hydroclathrus species, with the exception of Hydroclathrus minutus, in a highly-supported clade (Figure 1). The genetically identical Hydroclathrus specimens from Easter I. clustered with Hydroclathrus clathratus but were genetically distinct. We describe this species below as Hydroclathrus rapanuii Santiañez,

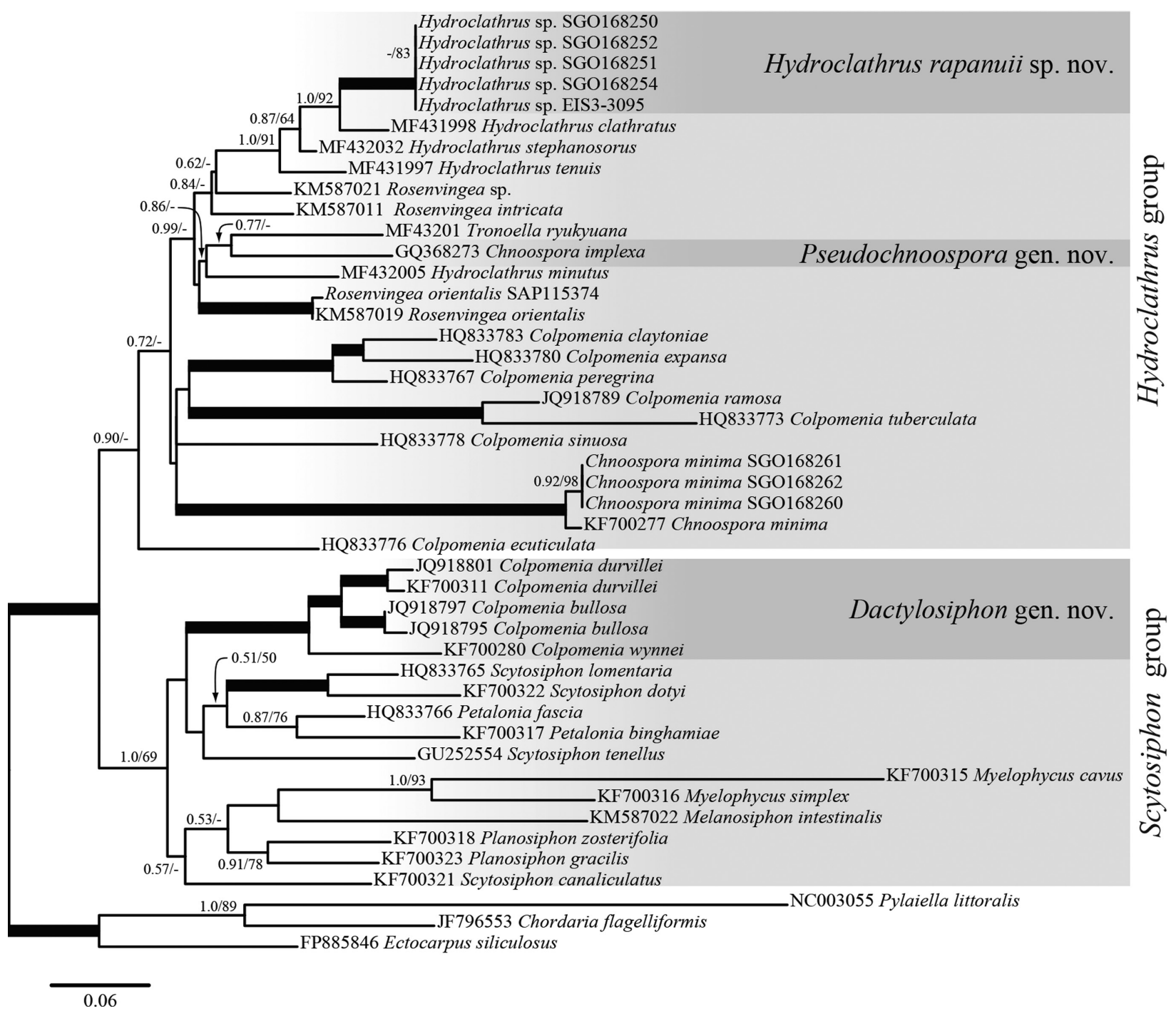

Figure 1: Maximum likelihood (ML) phylogenetic tree of Hydroclathrus and Chnoospora from Easter I. based on cox3 sequences. Support values appended at each node are Bayesian posterior probabilities (PP) and ML bootstrap percentages (BP), respectively. Highly supported nodes (PP: $\geq 0.98$ and BP: $\geq 95 \%$ ) are indicated by thickened lines. Values $<50 \% \mathrm{BP}$ and $<0.50 \mathrm{PP}$ are removed. Lineages with darkened background are newly proposed taxa. 
Macaya et Kogame sp. nov. Specimens of Chnoospora minima from Easter I. were also genetically identical and formed a highly-supported clade with $\mathrm{Ch}$. minima from southern Japan (Figure 1). The Chnoospora clade, however, did not include Chnoospora implexa, which grouped with the recently described taxa Tronoella ryukyuana Santiañez et Kogame and $H$. minutus, albeit with low support.

Similar to the cox3 gene-based phylogeny, the concatenated (cox3/rbcL/psaA; Figure 2) and plastid gene (Figure S1) phylogenies of the family Scytosiphonaceae showed that $H$. rapanuii was nested within the main Hydroclathrus clade. Hydroclathrus rapanuii was more closely related with the robust species $H$. clathratus and Hydroclathrus stephanosorus than to either of the thinner and fibrous Hydroclathrus tenuis or H. minutus.

Based on our concatenated tree, two major clades were suggested in the Scytosiphonaceae (Figure 2). One highly supported clade (which we designate as the "Scytosiphon group") consisted mainly of subtropical to temperate species from the genera Colpomenia, Petalonia, Planosiphon, Melanosiphon, Myelophycus and Scytosiphon. The other unresolved clade (the "Hydroclathrus group") was composed of tropical to warm temperate species of the genera Colpomenia, Chnoospora, Hydroclathrus, Rosenvingea Børgesen, and Tronoella Santiañez et Kogame. The relationships of most genera that are closely related to Hydroclathrus, including Chnoospora, Colpomenia and Rosenvingea, were unresolved. A particularly pronounced polyphyly was observed among Chnoospora species, where Ch. minima was consistently recovered as one of the early-diverged taxa within the "Hydroclathrus group" while Chnoospora implexa appeared to have diverged later. With respect to the genus Colpomenia, three lineages were apparent in our concatenated tree (Figure 2): Lineage 1 is represented by Colpomenia sinuosa (Mertens ex Roth) Derbès et Solier but also possibly includes Colpomenia tuberculata D.A. Saunders and Colpomenia ramosa W.R. Taylor (Figures 1 and S1); Lineage 2, represented by Colpomenia peregrina Sauvageau, includes Colpomenia claytoniae S.M. Boo, K.M. Lee, G.Y. Cho et W. Nelson and Colpomenia expansa (D.A.Saunders) Y.-P. Lee (Figure S1); and Lineage 3, as represented by Colpomenia bullosa, also includes Colpomenia durvillei and Colpomenia wynnei (Figure S1). Lineages 1 and 2 are found within the "Hydroclathrus group" (Figure 2) and, although their

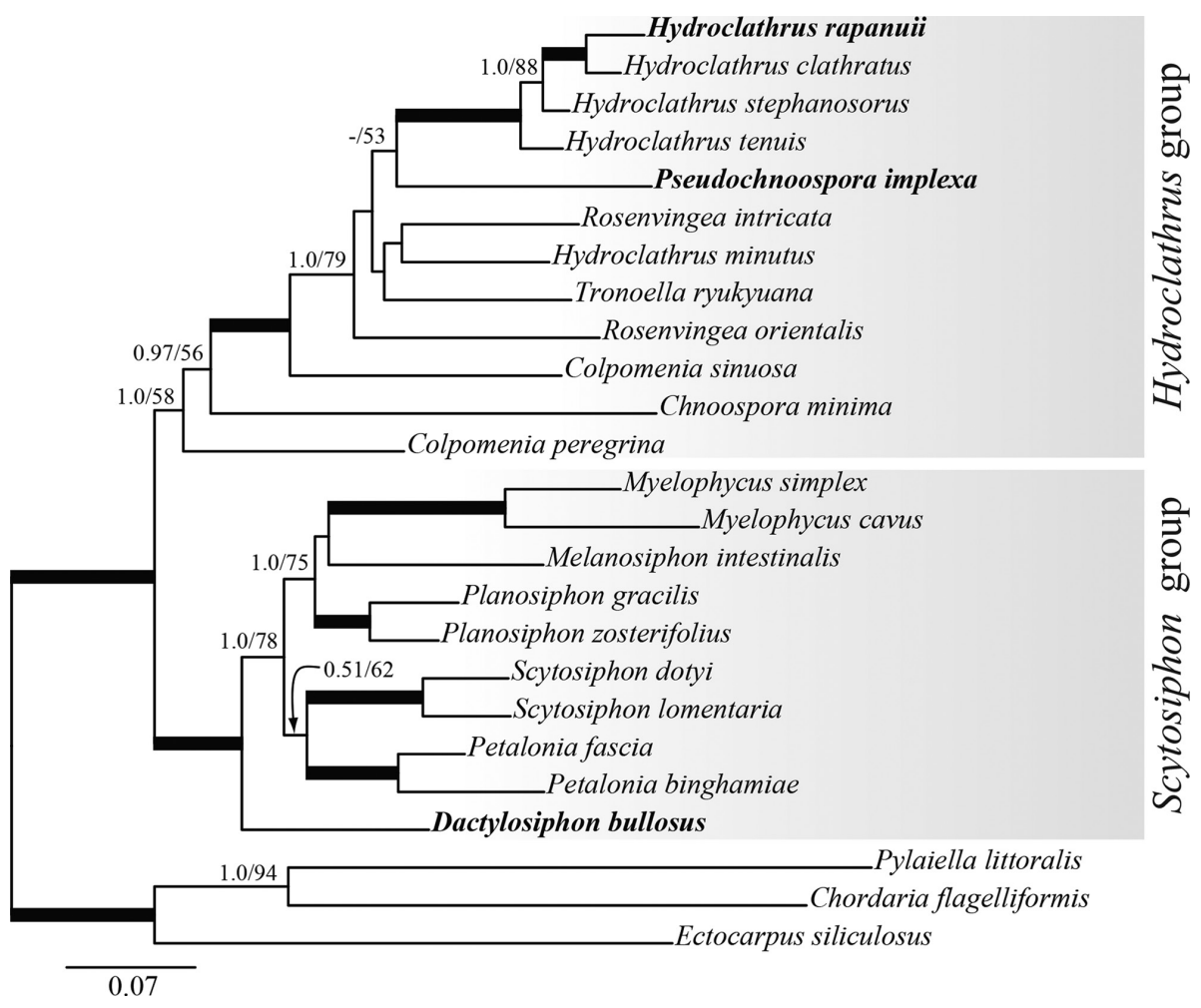

Figure 2: Maximum likelihood (ML) phylogenetic tree of multigene dataset ( $c o x 3, r b c \mathrm{~L}, p s a \mathrm{~A})$ of the family Scytosiphonaceae. Support values appended at each node are Bayesian posterior probabilities (PP) and ML bootstrap percentages (BP), respectively. Highly supported nodes (PP: $\geq 0.98$ and BP: $\geq 95 \%$ ) are indicated by thickened lines. Values $<50 \%$ BP and $<0.50$ PP are removed. Names of taxa in bold are the newly proposed species names or combinations in the family Scytosiphonaceae. 
phylogenetic positions remain ambiguous, both lineages were more closely related to each other than to Lineage 3. The latter clustered with high support in the "Scytosiphon group" (Figure 2).

\section{Taxonomic observations}

\section{Hydroclathrus rapanuii Santiañez, Macaya et Kogame sp. nov. (Figures 3-11)}

\section{Description}

Thalli saccate, up to $10 \mathrm{~cm}$ in diameter; membranes thin, 60-350 $\mu \mathrm{m}$ thick, surfaces furrowed, perforated with numerous holes. Cortical cells $4.5-12.5 \mu \mathrm{m}$ by $7-14 \mu \mathrm{m}$, narrowly to broadly oblong; medullary cells thin-walled, up to $190 \mu \mathrm{m}$ wide. Hair primordia in tufts, distally extending into hyaline hairs. Plurangial sori angular, block-like, often confluent with adjacent sori. Plurangia erect, quadriseriate, cylindrical to slightly clavate, 15-23 $\mu \mathrm{m}$ long.

\section{Holotype}

SG0168251 (Figures 3-11), Vaihu, Easter I., 1.5-2 m depth, 20 March 2016, E.C. Macaya; deposited in SGO.

\section{Isotypes}

SG0168250, SG0168252, Vaihu, Easter I., 20 March 2016, E.C. Macaya; deposited in SGO.

\section{Type locality}

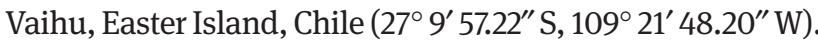

\section{Etymology}

Named in honor of the Rapanui people, the indigenous people of Easter Island.

\section{Distribution}

Currently only known from the type locality.

\section{Representative sequences}

Genbank accession numbers: $\operatorname{cox} 3=$ MG450663, psaA $=$ MG450664, $r b c \mathrm{~L}=\mathrm{MG} 251837$ (sequenced from SG0168251).

\section{Specimens examined}

SG0168250-SG0168255, Vaihu, Easter I., 20 March 2016, E.C. Macaya; EIS3-3095, Vaihu, Easter I., 18 November 2016, E.C. Macaya.

\section{Observations}

Thalli yellowish to light brown in color (Figure 4), becoming dark brown when dried on herbarium sheets (Figure 3), initially saccate (when young), later convoluted, attached to the substrate by rhizoids. Membranes 60-350 $\mu \mathrm{m}$ thick, irregularly perforated by holes of various sizes (Figures 3 and 4) rimmed by slightly folded to revolute margins. Membrane surfaces dimpled, furrowed, with hair tufts developing in depressions and creases (Figures 5 and 6).

Membranes composed of a layer of small pigmented cortical cells and 3-6 (rarely 7) layers of clear medullary cells (Figure 7). Cortical cells square or rectilinear to polygonal in surface view, (4-) 5-9 by (5-) 6-12 (-14) $\mu \mathrm{m}$ (Figures 5 and 6); in cross-section, thin-walled, variable in shape but mostly narrowly to broadly oblong, 4.5-12.5 $\mu \mathrm{m}$ wide by $7-14 \mu \mathrm{m}$ in height (Figure 8 ), apices smooth, sometimes domed to obtuse, those adjacent to hair primordia often becoming papillate. Medullary cells also thin-walled, progressively larger towards thallus interior, up to $190 \mu \mathrm{m}$ wide (Figure 7).

Hair primordia slightly clavate, often basally constricted, each extending into long hyaline hairs (Figures 2, 6 and 9), and clustered in groups of 4-20.

Plurangial sori angular and block-like, surrounding or adjacent to hair pits, often merging with nearby sori (Figure 6). Plurangial primordia differentiating from surface cortical cells (Figure 10), forming dense palisades. Mature plurangia cylindrical to slightly clavate, densely aggregated, quadriseriate (biseriate in lateral view), 15-23 $\mu \mathrm{m}$ long, each tier divided into four locules (Figure 11).

\section{Ecology}

Usually few individuals found at low to mid-intertidal rocky pools down to shallow subtidal ( $2 \mathrm{~m}$ depth) of protected and semi-protected sites in the island, associated with other brown algae such as Sargassum, Lobophora, Colpomenia and Stypopodium.

\section{Chnoospora minima (K. Hering) Papenfuss}

\section{Basionym}

Fucus minimus K. Hering 1841: 92.

\section{Synonyms}

Chnoospora pacifica J. Agardh fide Papenfuss 1956: 69.

Chnoospora fastigiata J. Agardh 1848: 171, nom. illeg., Chnoospora fastigiata var. pacifica (J. Agardh) J. Agardh fide Silva et al. 1996: 626. 

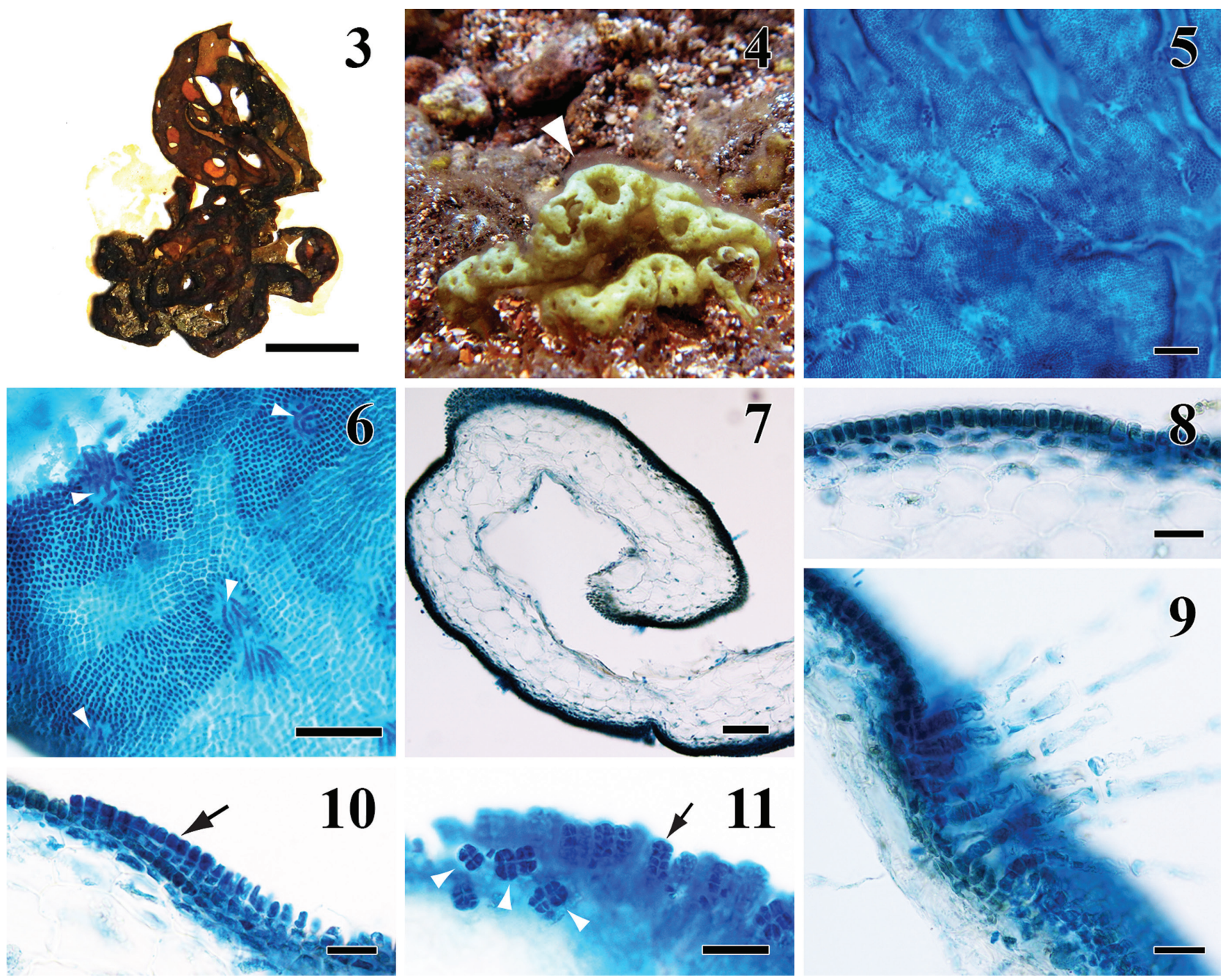

Figures 3-11: Hydroclathrus rapanuii Santiañez, Macaya et Kogame.

(3) Holotype specimen (SG0168251) showing partially saccate portions of the membranous thallus. Thallus is perforated with variously sized holes, larger ones show thickened margins as a result of inrolling. Scale bar $=1 \mathrm{~cm}$. (4) Young and perforated thallus of $H$. rapanuii from Easter I. showing its olive green color and phaeophycean hairs surrounding its thallus (arrowhead). (5) Portion of thallus membrane showing pits and channels that are often interconnected and are sites of hair growth (SG0168251). Scale bar=100 $\mu \mathrm{m}$. (6) Fertile portion of thallus showing plurangial sori formed around hair pits (arrowheads), often with angular margins (SG0168250). Scale bar $=100 \mu \mathrm{m}$. (7) Transverse section through a membrane showing the slightly revolute margins of the thallus, with a layer of pigmented cortical cells towards the outside and several layers of clear medullary cells towards the center (SG0168254). Scale bar $=100 \mu \mathrm{m}$. (8) Transverse section showing the narrowly to broadly oblong cortical cells that are slightly domed (SG0168252). Scale bar $=25 \mu \mathrm{m}$. (9) A group of hair primordia growing in a shallow depression, each extended into hyaline distal hairs (SG0168252). Scale bar $=25 \mu \mathrm{m}$. (10) Transverse section through the fertile portion of the holotype (SG0168251) showing plurangial initials (arrow) derived from cortical cells. Scale bar $=25 \mu \mathrm{m}$. (11) A group of mature plurangia that are arranged in vertical palisades, each divided into four columns (arrowheads) with four layers (arrow) (SG0168250). Scale bar $=25 \mu \mathrm{m}$.

\section{Lectotype}

HBG024509 collected by F. Krauss from Port Natal (Durban), South Africa: the lectotype was designated by Papenfuss (1956).

\section{Distribution}

Virtually cosmopolitan in tropical to subtropical IndoPacific (M.D. Guiry in Guiry and Guiry 2017).

\section{Specimens examined}

Easter Island: SGO168260-SGO168262, Tahai, Easter I., 15 March 2016, E.C. Macaya; EIS2-0193, Vaihu, Easter I., 20 March 2016, E.C. Macaya.

\section{Additional specimens examined}

Cook Islands: SAP115375, Ngatangiia, Rarotonga, 13 February 1993, A.D.R. N’Yeurt. Hawaiian Islands: SAP115377, 


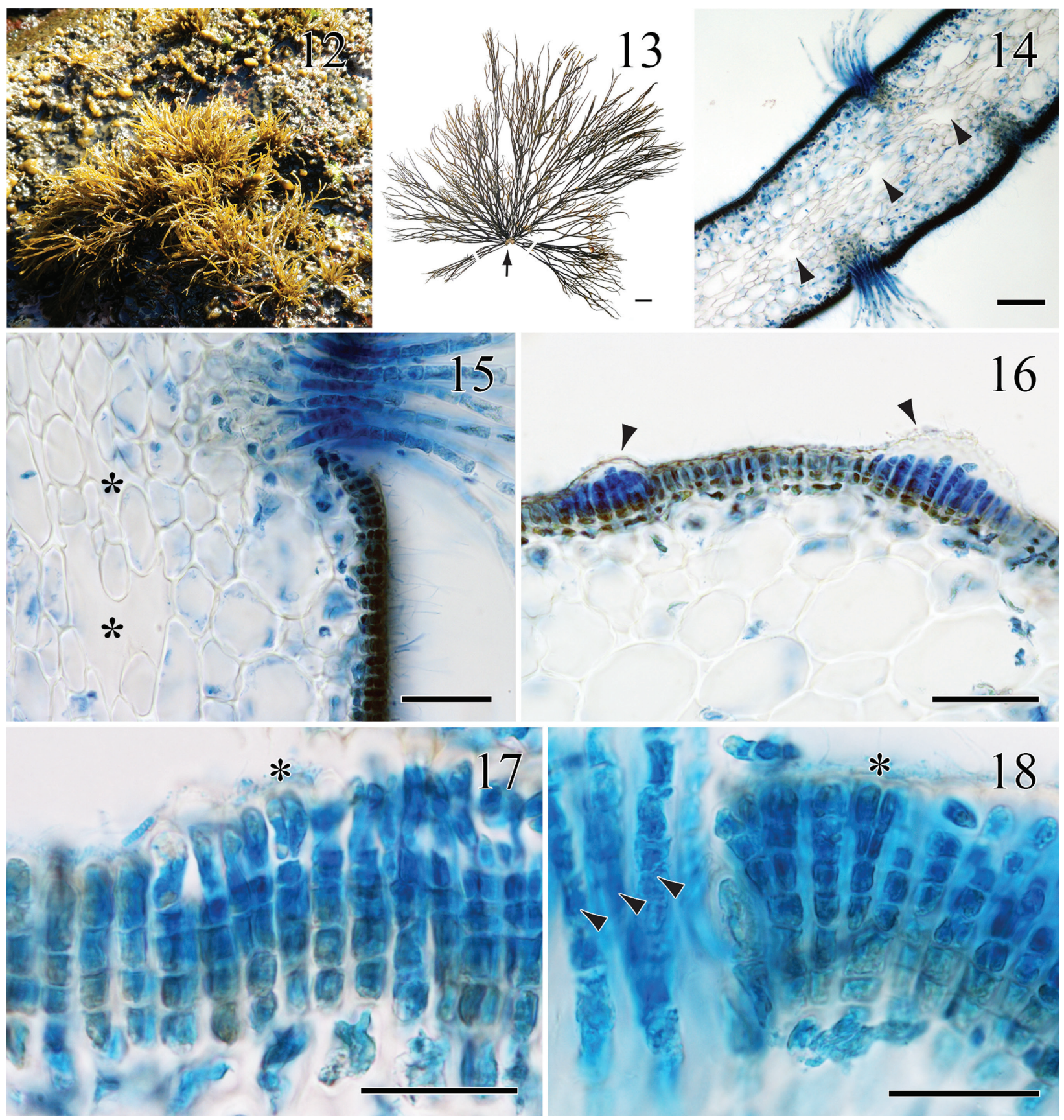

Figures 12-18: Chnoospora minima (K. Hering) Papenfuss.

(12) Exposed thalli of erect Chnoospora minima growing on rocks in Ahu Tahai, Easter Island. (13) Pressed herbarium specimen of $C h$. minima from Easter I. (SG0168262) showing its consolidated holdfast (arrow) and (sub) dichotomous branching. Scale bar $=1 \mathrm{~cm}$. (14) Three irregularly shaped hollow portions (arrowheads) in the medulla of the compressed branch (SG0168260). Scale bar $=100 \mu \mathrm{m}$. (15) Closer view of the intercellular space (asterisk) within the medulla (SG0168260). Scale bar $=50 \mu \mathrm{m}$. (16) Groups of hair primordia developing on the cortical layer, covered with loosened cuticle (arrowheads) (SG0168261). Scale bar $=50 \mu \mathrm{m}$. (17) Cortical layer of a specimen from Cook I. (SAP115375) showing uniseriate and biseriate (asterisk) plurangial initials derived from the outermost cortical cell. $\mathrm{Scale}$ bar $=25 \mu \mathrm{m}$. $(18)$ Young biseriate plurangia (asterisk) growing adjacent to hairs (arrowheads) (SAP115375). Scale bar $=25 \mu \mathrm{m}$.

Wittington Beach Park, Naalehu, 24 January 2008, A. Kurihara; SAP115378, Moloa’a Beach Park, Kauai, 15 February 2008, A. Kurihara. Japan: SAP115376, Uganzaki, Ishigaki, Okinawa, 10 March 2000, S. Kawaguchi and A. Kato.

\section{Observations}

Living thalli yellow-brown (Figures 12-18); drying dark brown basally, lighter distally (Figure 13). Thalli erect, in dense clumps, arising from consolidated holdfasts 
(Figure 13) attached in low to mid-intertidal (Figure 12), longer fronds lying prostrate on substratum when exposed during low tide.

Thalli up to $16 \mathrm{~cm}$ long, up to seven times (sub-) dichotomously branched, basally subterete, progressively thinner and compressed towards the blunt rounded apices (Figure 13).

Cortex 11-26 $\mu \mathrm{m}$ thick, composed of 2-4 layers of thick-walled, pigmented cells, bounding a medulla of intermixed small and large, thick-walled, clear medullary cells (Figures 14-16). Surface cells narrowly to broadly oblong, slightly domed, those at the inner layer rounded to cuboidal (Figures 14-16). Outer medullary cells rounded, becoming larger and narrowly elliptical internally, up to $150 \mu \mathrm{m}$ long by $100 \mu \mathrm{m}$ wide (Figures 14 and 15). Variously sized hollow portions occur in the medulla (Figures 14 and 15); these intercellular spaces discontinuous and without particular concentration throughout the thallus.

Hair primordia superficial and initially covered in a cuticle (Figure 14), or developing in deep pits subtended by several layers of small, clear subcortical cells, often forming a distinct arc (Figures 14 and 15), the primordia in dense tufts, usually aligned along the midlines of compressed axes towards the apices and extending into long hyaline hairs (Figures 14 and 15), these creating a whitish halo effect.

Plurangial sori often associated with hairs, covered with cuticles that are loosened as plurangia mature. Plurangial initials differentiating from cortical cells, becoming transversely biseriate (Figures 15 and 16); mature plurangia up to $50 \mu \mathrm{m}$ long, subdivided into smaller, squarish to rectangular locules $4-5 \mu \mathrm{m}$ by 2-5 $\mu \mathrm{m}$ in size.

\section{Discussion}

Our current understanding of global algal biodiversity and the phylogenetic relationships of macroalgae has been reshaped by the advent of DNA phylogenies. Using molecular phylogenetic tools, reports of high levels of cryptic and/or pseudo-cryptic diversity are common, especially among widespread species, such as Acinetospora crinita (Carmichael) Sauvageau (Yaegashi et al. 2015), Centroceras clavatum C. Agardh (Schneider et al. 2015), Gibsmithia hawaiiensis Doty (Gabriel et al. 2016), Lobophora variegata (J.V. Lamouroux) Womersley ex E.C. Oliveira (Vieira et al. 2014, 2016, Schultz et al. 2015), and Portieria hornemanii (Lyngbye) P.C. Silva (Payo et al. 2013).
Similarly, our molecular-assisted taxonomic studies of Hydroclathrus (Santiañez et al. 2018, this study) highlight the role of molecular tools in identifying and refining morpho-species boundaries among algae that have simple morphologies. Our studies also point to the importance of continuing to challenge the assumption that most, if not all, collections of Hydroclathrus made throughout the tropical to warm-temperate waters belong to a single, cosmopolitan, and highly polymorphic species, Hydroclathrus clathratus. For example, wide-scale sampling of Hydroclathrus in subtropical to warm-temperate coasts of Japan indicated that $H$. clathratus can be sympatric with Hydroclathrus stephanosorus; the latter has been overlooked or misidentified, and was shown to be more widely distributed in Japan than the former (Santiañez et al. 2018).

With Hydroclathrus rapanuii, we add one more putatively endemic species to the seaweed flora of Easter I. Like H. stephanosorus from Lord Howe I., Australia (Kraft and Abbott 2003) and Hydroclathrus minutus from Okinawa I. (Santiañez et al. 2018), its type locality is a small Pacific volcanic island, and this is also true of the recently described scytosiphonacean species Petalonia tatewakii Kogame et A. Kurihara (Kogame et al. 2011), Petalonia tenuis K. Matsumoto et S. Shimada (Matsumoto et al. 2014), and Tronoella ryukyuana Santiañez et Kogame (Santiañez et al. 2018). Extensive taxon sampling of volcanic islands will likely result in new taxa discoveries right across the algal phyla.

Specimens of $H$. rapanuii were similar in habit to young $H$. clathratus but can be distinguished based on larger cortical cells, fewer medullary cell layers, and angular to block-like plurangial sori (Table 1). Hydroclathrus rapanuii resembles $H$. stephanosorus and Hydroclathrus tumulis in the breadth of the membrane surrounding the perforations. However, it can be differentiated from $H$. stephanosorus by its plurangial sori (angular and blocklike as opposed to nearly circular soral outline), cortical cell shape (oblong to broadly oblong vs. broadly rounded), and thinner thallus membranes (Table 1). Although the angular and block-like sori of $H$. rapanuii were similar to those of $H$. tumulis, the latter has subapiculate cortical cells, laxly arranged and apparently stalked plurangia, and has an apparent restriction to deep waters (Kraft and Abbott 2003).

Chnoospora minima specimens from Easter I. agree well the reports of the species from Hawaii (Fotos 1981, Abbott and Huisman 2004), Philippines (Trono 1997), French Polynesia (N’Yeurt and Payri 2006), Australia (Kraft 2009), and South Africa (Anderson et al. 2016), except for the presence of hollow areas in the medulla. We observed 


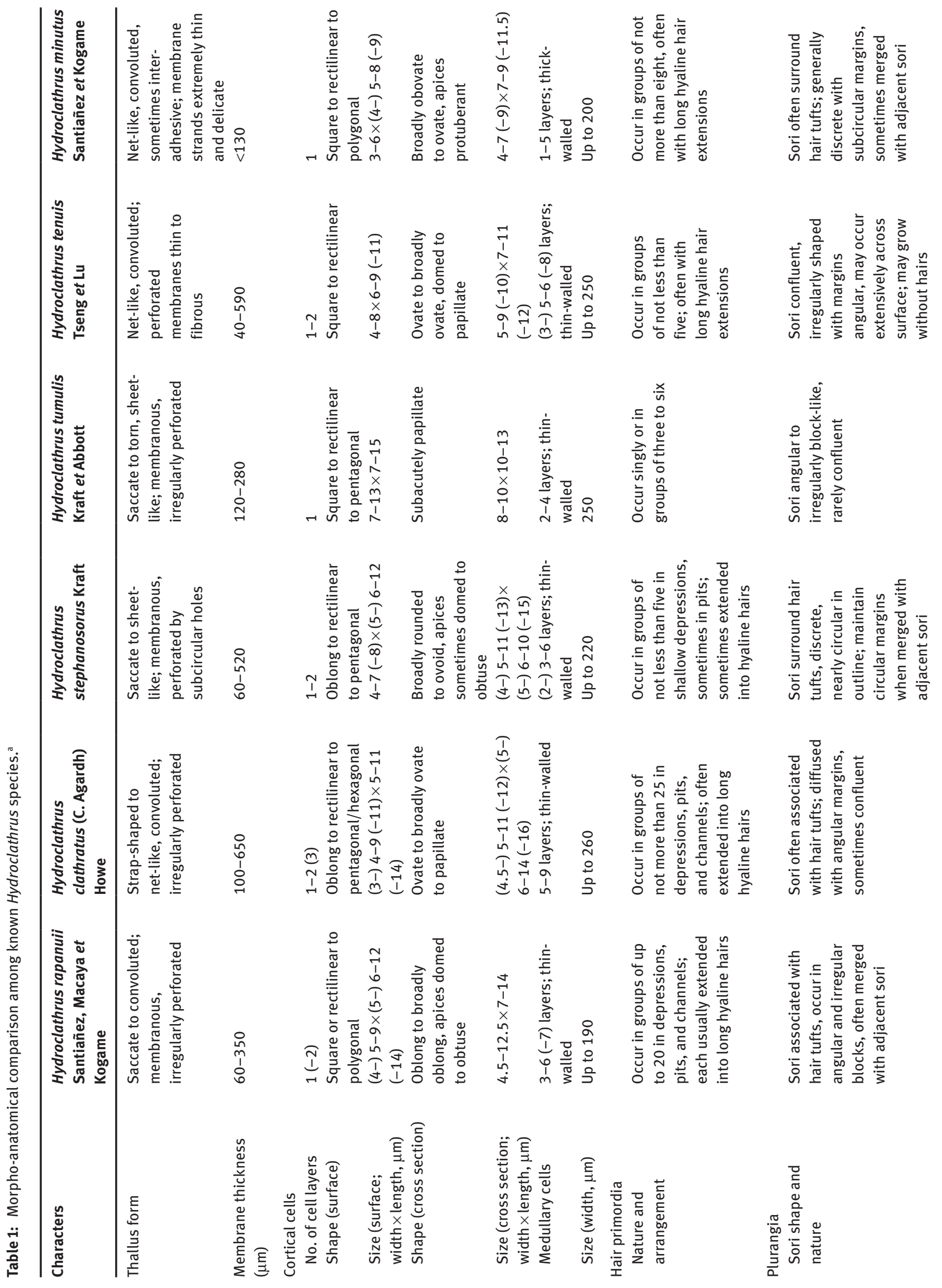




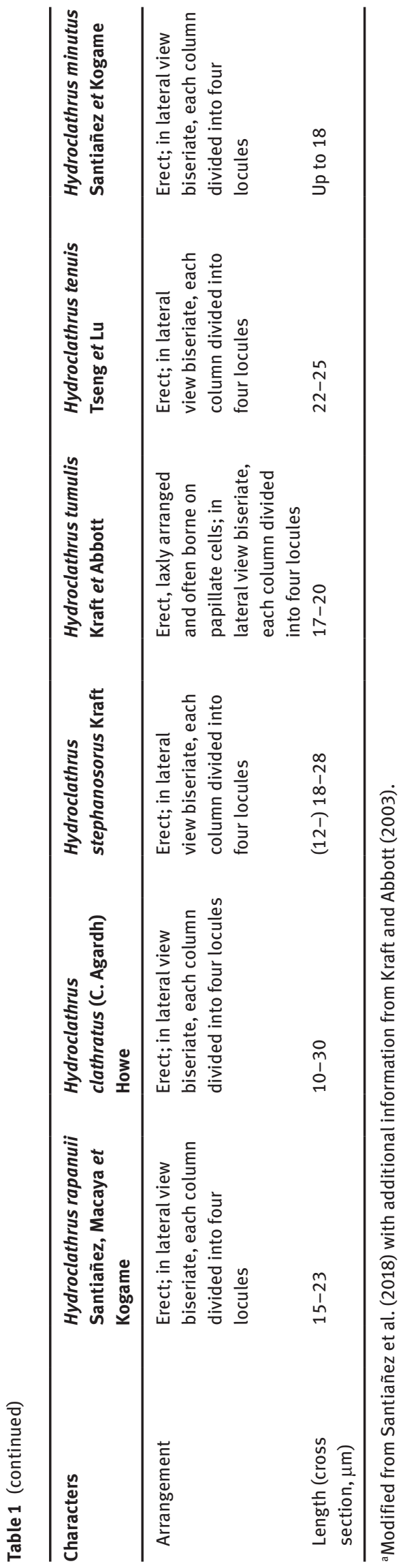

these variously sized hollowed areas in the medullas of thalli collected from within the central and western Pacific localities (i.e. southern Japan, Hawaiian Islands, and Cook Islands), as well as in the Indian Ocean (Anderson et al. 2016). The unattached Ch. minima reported from the deep waters of New Zealand were slightly longer than our Easter I. specimens and also appear to have hollow portions (Nelson and Duffy 1991, fig. 3), albeit they were not mentioned by the authors. Smaller and relatively thinner thalli of Hawaiian specimens showed inconspicuous medullary gaps, and it is likely that this character may have been overlooked or was thought to be taxonomically insignificant.

No fertile Ch. minima specimen was found among our Easter I. collections, but those from Cook and Hawaiian Is. possessed mature plurangia. Similar to those reported by J. Agardh (1848) and Barton (1898) in Chnoospora fastigiata J. Agardh (=Ch. minima), we also saw the presence of a cuticle on these uni- to biseriate plurangia. Plurangial cuticles in Ch. minima have not been mentioned in other reports (Fotos 1981, Trono 1997, Abbott and Huisman 2004, Kraft 2009, Anderson et al. 2016). Kraft (2009) suggested that the plurangia illustrated by Fotos (1981, figs. 4, 11) and Barton (1898, pl. 28, figs. 4, 5) were "anticlinal cortical filaments that are typical of vegetative cells lining the flat faces of the fronds", as was illustrated in his fig. 38G, $\mathrm{H}$. In contrast to his opinion, we confirm that those illustrated by Fotos and Barton were plurangia, similar to those found in our specimens and the South African specimen (Anderson et al. 2016). We do agree, however, that those illustrated by Kraft (2009, fig. 38I) were plurangial initials and were similar to those we observed (Figures 17 and 18).

When J. Agardh established the genus Chnoospora in 1847, he described two species: Chnoospora pacifica J. Agardh from Pacific Mexico and Chnoospora atlantica J. Agardh from Venezuela. A year later (Agardh 1848) synonymized these two species to Chnoospora fastigiata and described two additional species, Chnoospora implexa J. Agardh and Chnoospora pannosa J. Agardh. On both occasions, he failed to designate the generitype species. Papenfuss (1956: 69) proposed the conspecificity of $C h$. fastigiata with Fucus minimus K. Hering and subsequently combined these names as Ch. minima based on Hering's priority. In the same publication, Papenfuss also designated Herings's specimen [HBG024509, collected by F. Krauss from Port Natal (Durban), South Africa; currently deposited at the Herbarium Hamburgense of the University of Hamburg, Germany], as the lectotype. He also noted the similarity of Hering's specimen to the South African Ch. minima (as Ch. fastigiata) reported by Barton (1898). As mentioned earlier, the Ch. minima specimens we examined also agree well with Barton's specimens, as well as those illustrated in 
Anderson et al. (2016) from South Africa. Taking all these observations into consideration, and because it has not been done yet (M.D. Guiry in Guiry and Guiry 2017), we herein designate $\mathrm{Ch}$. minima as the generitype of the genus Chnoospora.

Similar to previous works on the Scytosiphonaceae (e.g. Cho et al. 2006, Lee et al. 2014a, McDevit and Saunders 2017), two major phyletic groups were apparent (i.e. the "Scytosiphon group" and "Hydroclathrus group") in our molecular trees. Species found in the "Scytosiphon group" have upright, elongate and terete to flattened thalli that are hollow, partially hollow or solid in construction. Some members of this group produce only unilocular zoidangia in the prostrate sporophyte stage (Kogame et al. 1999, Kogame and Masuda 2001, Cho et al. 2006), and are distributed in subtropical to temperate waters (Kogame et al. 1999). The "Hydroclathrus group" includes species of varied morphologies ranging from upright to spreading, of either hollow or solid construction, and saccate to branched, some branches anastomosing to varying degrees. Species in this group are found in tropical to warm temperate waters and have prostrate sporophytes that produce both uni- and plurilocular zoidangia (Kogame et al. 1999, Kogame 2001, Cho et al. 2006).

Paraphyly and polyphyly of some genera have been a consistent theme among the Scytosiphonaceae since the pioneering molecular phylogenetic work by Kogame et al. (1999). Despite numerous follow-up studies, taxonomic revisions to achieve monophyly have been slow. Kogame et al. (1999) suggested that the morphology of prostrate sporophyte thalli (i.e. thallus structure and presence/absence of plurilocular zoidangia) are important taxonomic criteria at the generic level. However, as information on life histories and input of genetic data from other scytosiphonacean species have been scarce, no formal proposals have yet been made to settle the unresolved relationships in the family. Recently, members of the Scytosiphonaceae have received considerable attention, resulting in an increase of information on the life history, morphology and phylogeny of species of Chnoospora (Kogame 2001), Colpomenia (Kogame and Masuda 2001, Boo et al. 2011, Lee et al. 2012, Lee et al. 2014a), Hydroclathrus (Kraft and Abbott 2003, Santiañez et al. 2018), Melanosiphon (Lee et al. 2014b), Myelophycus (Cho et al. 2006), Rosenvingea (West et al. 2010, Lee et al. 2014b) and Petalonia (Kogame et al. 2011, Matsumoto et al. 2014). Collectively, these works have provided insights into the taxonomic complexities but have also paved the way to clarifying specific and generic boundaries in the Scytosiphonaceae. In an attempt to partially resolve the non-monophyly in Petalonia and Scytosiphon, McDevit and Saunders (2017) recently proposed the recognition of Planosiphon. Similar to previously mentioned reports, relationships among species of Colpomenia, Chnoospora, Hydroclathrus, Rosenvingea and Scytosiphon still remain unresolved.

In the current work, Colpomenia did not resolve as monophyletic and was segregated into at least three distinct lineages: two of these (Lineages 1 and 2) were found within the "Hydroclathrus group" whereas one (Lineage 3) was within the "Scytosiphon group". The relationships of the Colpomenia lineages within the "Hydroclathrus group" were not resolved, but these are represented by species with globular/saccate to amorphously contoured, hollow thalli. Meanwhile, Colpomenia "Lineage 3", whose species have upright, elongate (finger-like), hollow thalli, was sister to all other taxa within the "Scytosiphon group". In addition, compared to species of Lineage 1 (e.g. C. sinuosa), which has a prostrate sporophyte that produces both uni- and plurilocular zoidangia, C. bullosa of "Lineage 3" produces only unilocular zoidangia in its prostrate sporophyte thallus (Kogame et al. 1999). Considering these distinct differences, we believe it is best to remove the three former Colpomenia species nested within the "Scytosiphon group" to a new genus Dactylosiphon.

We have previously suggested the possibility of segregating Ch. implexa from the genus Chnoospora based on genetic and morphological differences (Santiañez et al. 2018). In our current and in previous studies on the Scytosiphonaceae, the generitype Ch. minima was always segregated from Ch. implexa by at least representatives of Rosenvingea and Colpomenia, with moderate to high levels of support. This observed phylogenetic segregation is reflected in the distinct morpho-anatomical and ecological differences among these taxa outlined in Table 2.

Based on morphological and molecular phylogenetic criteria, we herein formally segregate $C h$. implexa and species in "Lineage 3" of Colpomenia from their current generic affiliation and propose that Pseudochnoospora gen. nov. and Dactylosiphon gen. nov., respectively, be recognized to accommodate them.

\section{Taxonomic proposals}

\section{Pseudochnoospora Santiañez, G.Y. Cho et Kogame gen.} nov.

\section{Description}

Thalli decumbent, branched, with branches attached to the substrata and to other branches at various points; axes solid, terete to compressed. Cortex up to two layers of small, pigmented cells. Medullary cells clear, thin-walled, 


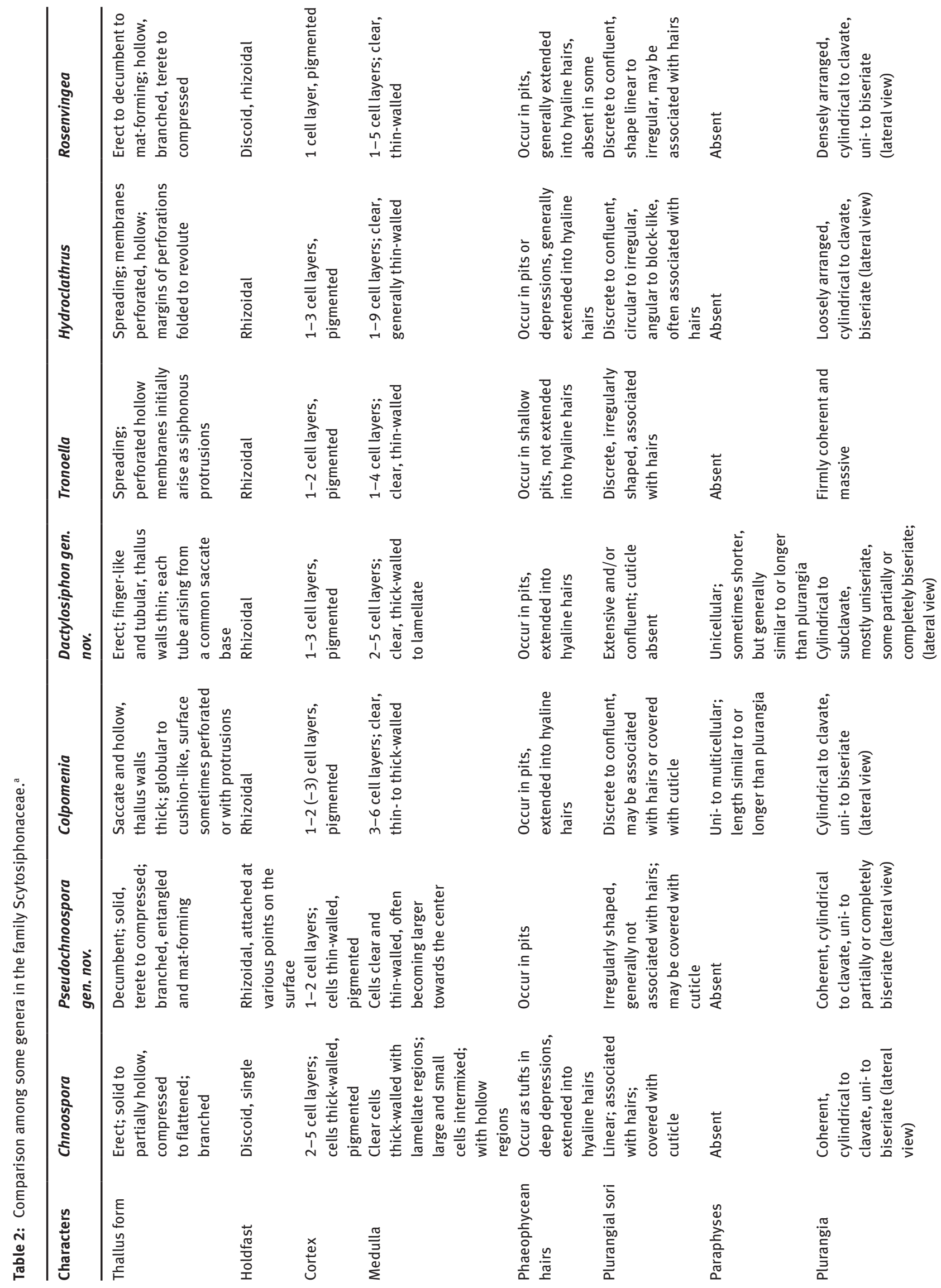




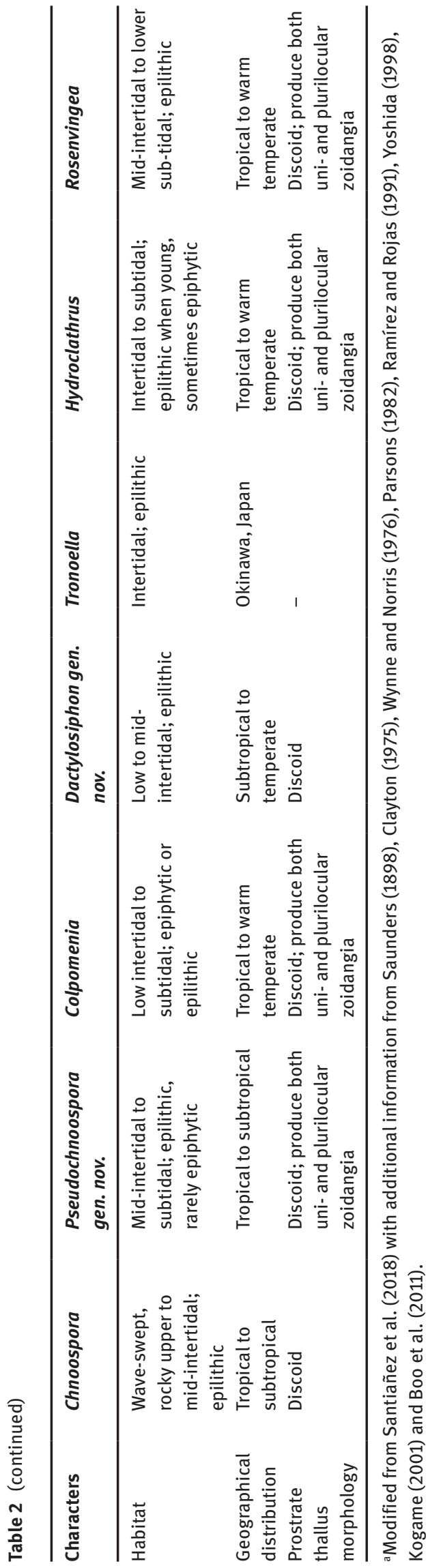

becoming larger centrally. Plurangia covered with cuticle, coherent, cylindrical to clavate, uniseriate to partially to completely biseriate, paraphyses absent. Prostrate sporophyte produces both uni- and plurilocular zoidangia.

\section{Type species}

Pseudochnoospora implexa (J. Agardh) Santiañez, G.Y. Cho et Kogame comb. nov.

\section{Etymology}

Pseudochnoospora, or the "false Chnoospora", is in reference to the previous erroneous assignment of the taxon to the genus Chnoospora.

\section{Pseudochnoospora implexa (J. Agardh) Santiañez, G.Y. Cho et Kogame comb. nov.}

Basionym

Chnoospora implexa J. Agardh 1848: Species genera et ordines algarum, seu descriptiones succinctae specierum, generum et ordinum, quibus algarum regnum constituitur. Volumen primum: Algas fucoideas complectens: 172.

\section{Synonyms}

Dictyota obtusangula Kützing 1859: 13, Chnoospora obtusangula (Kützing) Sonder 1871: 45 fide Grunow 1874: 25.

Chnoospora pannosa J. Agardh 1848: 172 fide Kraft 2009: 108.

\section{Holotype}

BM000569565, Tor, Sinai Peninsula, W. Schimper; deposited in BM.

\section{Distribution}

Tropical to subtropical waters (M.D. Guiry in Guiry and Guiry 2017).

\section{Remarks}

When J. Agardh (1848) formally described Sphaerococcus implexus Hering nom. nud. as a new species, he placed it in Chnoospora under the heading "Species inquirenda". Its original disposition has since been followed despite the absence of studies to confirm its generic assignment. Descriptions of "Ch. implexa" from various localities has been consistent, with Kraft (2009) providing detailed morphological work on the species based on Australian and Hawaiian samples. Morpho-anatomical observations 
on "Ch. implexa" clearly indicate that it is different from the generitype Ch. minima (Table 2). That is, "Ch. implexa" can be differentiated from Ch. minima in possessing solid, decumbent and inter-adhesive thalli that are attached to various points on the substratum (vs. erect, freely branching, and partially hollow thalli that were densely growing from a consolidated holdfast) and in having thinwalled cortical and medullary cells (vs. thick-walled cells; Table 2). In addition, previous molecular phylogenetic studies (e.g. Cho et al. 2006, Santiañez et al. 2018) pointed to the polyphyly of the genus Chnoospora. Pseudochnoospora implexa (as Ch. implexa) in culture was shown to have a prostrate sporophyte that produces both uni- and plurilocular zoidangia (Kogame 2001).

\section{Dactylosiphon Santiañez, K.M. Lee, S.M. Boo et Kogame gen. nov.}

\section{Description}

Thalli composed of hollow, elongate (finger-like) tubes, each tapering to an attenuate to cuneate basal portion and arising from a saccate base. Interiors hollow, bounded by several layers of large, clear, thick-walled medullary cells; outer layer composed of small pigmented cortical cells. Plurangia occurring extensively throughout the surface, always associated with short to slightly longer paraphyses, the plurangia mostly uniseriate, some partially to completely biseriate.

\section{Type species}

Dactylosiphon bullosus (D.A. Saunders) Santiañez, K.M. Lee, S.M. Boo et Kogame comb. nov.

\section{Etymology}

Named after the finger-like (Greek: dactylo-) and siphonous thalli of the species belonging to this genus.

Dactylosiphon bullosus (D.A. Saunders) Santiañez, K.M. Lee, S.M. Boo et Kogame comb. nov.

\section{Basionym}

Scytosiphon bullosus D.A. Saunders 1898: Proceedings of the California Academy of Science, Series 3, Botany 1: 163, pl. XXXI: figs 1-7.

\section{Synonym}

Colpomenia bullosa (D.A. Saunders) Yamada in Yamada et Kinoshita 1948: 6, pl. 4.

\section{Type locality}

Pacific Grove, California, USA.

\section{Distribution}

Temperate waters of the Pacific (Lee et al. 2012).

\section{Remarks}

In culture, Dactylosiphon bullosus (as Colpomenia bullosa) was shown to have a prostrate sporophyte that produces only unilocular zoidangia, similar to the other species reported within the "Scytosiphon group" (Kogame 1994, Kogame and Masuda 2001, Kogame et al. 1999). This character may be used for generic delineation, but life history studies on the other species included in Dactylosiphon are yet to be conducted. Dactylosiphon bullosus (as C. bullosa) has been placed in either Scytosiphon or Colpomenia by various authors (Parsons 1982), primarily in the latter based on the opinion of Yamada (1948), with Hollenberg and Abbott (1966) providing some details for segregating it from Scytosiphon. The confused taxonomy of the species is understandable, considering the wide generic circumscription of both Colpomenia and Scytosiphon.

\section{Dactylosiphon durvillei (Bory de Saint-Vincent) Santiañez, K.M. Lee, S.M. Boo et Kogame comb. nov.}

\section{Basionym}

Aspercoccus durvillei Bory de Saint-Vincent 1828: Botanique, Cryptogamie. In (Duperrey, L.I. Eds): Voyage autour du monde, exécuté par ordre du Roi, sur la corvette de Sa Majesté, la Coquille, pendant les années 1822, 1823, 1824 et 182: 200, pl. 11: fig. 3 (as “durvillaei”).

\section{Synonyms}

Colpomenia durvillei (Bory de Saint-Vincent) M.E. Ramírez in Ramírez et Rojas 1991: 17.

Colpomenia phaeodactyla M.J. Wynne et J.N. Norris 1976 fide Lee et al. 2014a: 485.

\section{Type locality}

Concepcion, Chile.

\section{Distribution}

Temperate waters of the Pacific (Lee et al. 2012).

\section{Remarks}

The taxonomy and molecular phylogeny of Dactylosiphon durvillei (=Colpomenia durvillei) relative to other 
elongate species of Colpomenia (= Dactylosiphon) has been reviewed in detail by Lee et al. (2012), where it is suggested that $C$. phaeodactyla may be conspecific with C. durvillei. Based on morphological and phylogenetic analyses on an elongate Colpomenia from Las Cuevas, Sonora, Mexico (near the type locality of $C$. phaeodactyla) and Chile, Lee et al. (2014a: 485) synonymized $C$. phaeodactyla with $C$. durvillei based on nomenclatural priority.

\section{Dactylosiphon wynnei (K.M. Lee, R. Riosmena- Rodriguez, Kogame et S.M. Boo) Santiañez, K.M. Lee, S.M. Boo et Kogame comb. nov.}

\section{Basionym}

Colpomenia wynnei K.M. Lee, R. Riosmena-Rodriguez, Kogame et S.M. Boo 2014: Phycologia 53 (5): 481, figs. 1-7.

\section{Type locality}

Hoedong, Jindo, Korea.

\section{Distribution}

Southern Korea and Japan (Lee et al. 2014a).

\section{Remarks}

Dactylosiphon wynnei is a recently described species (as C. wynnei) from Korea and Japan. It is unique among its congeners in possessing adventitious branchlets along the length of its contorted, mature elongate sacs.

Acknowledgements: WJES is funded by the Ministry of Education, Japan (MEXT) under the Monbukagakusho Scholarship Grant. ECM is funded by the Chilean Millennium Initiative (NC120030) grant. We are indebted to Carolina Sandoval for her assistance in collecting and preparing voucher specimens of the Hydroclathrus and Chnoospora from Easter Island used in this study. We thank S. Kawaguchi, A. Kato, A. Kurihara, A.D.R. N’Yeurt for the Chnoospora samples and P.J.L. Geraldino for the Rosenvingea orientalis sample. We also thank our reviewers for their insightful comments and suggestions that have considerably improved this manuscript. The scans of the type specimen of Chnoospora minima and Chnoospora implexa we examined in this study were courtesy of the Herbarium Hamburgense, University of Hamburg, Germany (HBG) and the Trustees of the Natural History Museum, London (BM), respectively.

\section{References}

Abbott, I.A. and J.M. Huisman. 2004. Marine green and brown algae of the Hawaiian Islands. Bishop Museum Press, Honolulu. pp. 259.

Agardh, J.G. 1847. Nya alger från Mexico. Öfversigt af Kongl. Vetenskaps-Adademiens Förhandlingar, Stockholm 4: 5-17.

Agardh, J.G. 1848. Species genera et ordines algarum, seu descriptiones succinctae specierum, generum et ordinum, quibus algarum regnum constituitur. Volumen primum: Algas fucoideas complectens. C.W.K. Gleerup, Lund. pp. 363.

Anderson, R.J., H. Stegenga and J.J. Bolton. 2016. Seaweeds of the South African South Coast. World Wide Web electronic publication, University of Cape Town, http://southafrseaweeds.uct. ac.za; Accessed on 17 August 2017.

Barton, S.E. 1898. On the fruit of Chnoospora fastigiata. J. Linn. Soc., Bot. 33: 507-508.

Boo, S.M., K.M. Lee, G.Y. Cho and W. Nelson. 2011. Colpomenia claytonii sp. nov. (Scytosiphonaceae, Phaeophyceae) based on morphology and mitochondrial cox3 sequences. Bot. Mar. 54: 159-167.

Børgesen, F. 1924. Marine Algae from Easter Island. In: (Skottsberg, C., ed) The Natural History of Juan Fernandez and Easter Island Vol. 2. Almquist \& Wiksells, Uppsala. pp. 247-309.

Bory de Saint-Vincent, J.B.M. 1828. Botanique, Cryptogamie. In: (Duperrey, L.I., ed): Voyage autour du monde, exécuté par ordre du Roi, sur la corvette de Sa Majesté, la Coquille, pendant les années 1822, 1823, 1824 et 1825. Paris: Bertrand. pp. 97-200.

Cho, G.Y., K. Kogame and S.M. Boo. 2006. Molecular phylogeny of the family Scytosiphonaceae (Phaeophyceae). Algae 21: 175-183.

Clayton, M.N. 1975. A study of variation in Australian species of Colpomenia (Phaeophyta, Scytosiphonales). Phycologia 14: 187-195.

Etcheverry, D.H. 1986. Algas marinas bentónicas de Chile. UNESCO (Regional office of Science and Technology for Latin America and the Caribbean), Montevideo, Uruguay. pp. 1-379.

Fernández, M., P. Pappalardo. M.C. Rodríguez-Ruiz and J.C. Castilla. 2014. Synthesis of the state of knowledge about species richness of macroalgae, macroinvertebrates and fishes in coastal and oceanic waters of Easter and Salas y Gómez islands. Lat. Am. J. Aquat. Res. 42: 760-802.

Fotos, S.F. 1981. Observations on Chnoospora minima (Hering) Papenfuss (Phaeophyta, Scytosiphonales) in the field and in culture. Jap. J. Phycol. 29: 101-108.

Gabriel, D., S.G.A. Draisma, T. Sauvage, W.E. Schmidt, T. Schils, P.-E. Lim, J. Harris and S. Fredericq. (2016). Multilocus phylogeny reveals Gibsmithia hawaiiensis (Dumontiaceae, Rhodophyta) to be a species complex from the Indo-Pacific, with the proposal of G. eilatensis sp. nov. Phytotaxa 277: 1-20.

Grunow, A. 1874. Algen der Fidschi-, Tonga- und Samoa-Inseln, gesammelt von Dr. E. Graeffe. Journal des Museum Godeffroy 3: $23-50$.

Guiry, M.D. and G.M. Guiry. 2017. AlgaeBase. World-wide electronic publication, National University of Ireland, Galway. http://www. algaebase.org; Accessed on 29 June 2017.

Hering, C. 1841. Diagnoses algarum novarum a cl. Dre. Ferdinand Krauss in Africa Australi lectarum, auctore Dno. Ann. Mag. Nat. Hist. 8: 90-92. 
Hollenberg, G.J. and I.A. Abbott. 1966. Supplement to Smith's marine algae of the Monterey Peninsula. Stanford University Press, Stanford, California. pp. 130.

Huelsenbeck, J.P. and F.R. Ronquist. 2001. MrBayes: Bayesian inference of phylogeny. Biometrics 17: 754-755.

Kogame, K. 1994. A taxonomic study of the family Scytosiphonaceae (Scytosiphonales, Phaeophyceae) in Japan. Ph.D. dissertation, Hokkaido University, Sapporo. pp. 158.

Kogame, K. 2001. Life history of Chnoospora implexa (Chnoosporaceae, Phaeophyceae) in culture. Phycol. Res. 49: 123-128.

Kogame, K. and M. Masuda. 2001. Crustose sporophytes of Colpomenia bullosa (Scytosiphonaceae, Phaeophyceae) in nature. Cryptogamie Algol. 22: 201-208.

Kogame, K., T. Horiguchi and M. Masuda. 1999. Phylogeny of the order Scytosiphonales (Phaeophyceae) based on DNA sequences of $r b c \mathrm{~L}$, partial $r b c S$, and partial LSU nrDNA. Phycologia 38: 496-502.

Kogame, K., A. Kurihara, G.Y. Cho, K.M. Lee, A.R. Sherwood and S.M. Boo. 2011. Petalonia tatewakii sp. nov. (Scytosiphonaceae, Phaeophyceae) from the Hawaiian Islands. Phycologia 50: 563-573.

Kraft, G.T. 2009. Algae of Australia. Marine benthic algae of Lord Howe Island and the southern Great Barrier Reef, 2. Brown algae. Australian Biological Resources Study and CSIRO Publishing, Canberra and Melbourne. pp. 364.

Kraft, G.T. and I.A. Abbott. 2003. Hydroclathrus (Scytosiphonaceae, Phaeophyceae): conspectus of the genus and proposal of new species from Australia and Hawaii. Phycol. Res. 51: 244-258.

Lee, K.M., A. Mansilla, W.A. Nelson and S.M. Boo. 2012. Colpomenia durvillei (Scytosiphonaceae, Phaeophyceae): its distribution and relationships with other elongate species of the genus. Bot. Mar. 55: 367-375.

Lee, K.M., R. Riosmena-Rodriguez, K. Kogame and S.M. Boo. $2014 a$. Colpomenia wynnei sp. nov. (Scytosiphonaceae, Phaeophyceae): a new species of marine algae from Northeast Asia. Phycologia 53: 480-487.

Lee, K.M., D.D. Hong, and S.M. Boo. 2014b. Phylogenetic relationships of Rosenvingea (Scytosiphonaceae, Phaeophyceae) from Vietnam based on cox3 and psaA sequences. Algae 29: 289-297.

Matsumoto, K., K. Ichihara and S. Shimada. 2014. Taxonomic reinvestigation of Petalonia (Phaeophyceae, Ectocarpales) in southeast of Honshu, Japan, with a description of Petalonia tenuis sp. nov. Phycologia 53: 127-136.

McDevit, D.M. and G.W. Saunders. 2017. A molecular investigation of Canadian Scytosiphonaceae (Phaeophyceae) including descriptions of Planosiphon gen. nov. and Scytosiphon promiscuus sp. nov. Botany 95: 653-671.

Miller, M.A., W. Pfeiffer W. and T. Schwartz. 2010. Creating the CIPRES Science Gateway for inference of large phylogenetic trees. In: Proceedings of the Gateway Computing Environments Workshop (GCE). Orleans, LA, pp. 1-8.

Nelson, W.A. and C.A.J. Duffy. 1991. Chnoospora minima (Phaeophyta) in Port Underwood, Marlborough - a curious new algal record for New Zealand. New Zeal. J. Bot. 29: 341-344.

N'Yeurt, A.D.R. and C.E. Payri. 2006. Marine algal flora of French Polynesia I. Phaeophyceae (Ochrophyta, brown algae). Cryptogamie Algol. 27: 111-152.
Papenfuss, G.F. 1956. Notes on South African marine algae. IV. J. S. Afr. Bot. 22: 65-77.

Nylander, J.A.A. 2004. MrModeltest v2. Program distributed by the author. Evolutionary Biology Centre, Uppsala University.

Parsons, M.J. 1982. Colpomenia (Endlicher) Derbès et Solier (Phaeophyta) in New Zealand. New Zeal. J. Bot. 20: 289-301.

Payo, D.A., F. Leliaert, H. Verbruggen, S. D’hondt, H.P. Calumpong, and O. De Clerck. 2013. Extensive cryptic species diversity and fine-scale endemism in the marine red alga Portieria in the Philippines. Proc. R. Soc. London, B 280: 20122660.

Ramírez, J.J. and D.G. Müller. 1991. New records of benthic marine algae from Easter Island. Bot. Mar. 34: 133-137.

Ramírez, M.E. and V.G. Rojas. 1991. El genero Colpomenia (F.C. Mertens ex Roth) Derbes et Solier (Phaeophyceae), en Chile. Bol. Mus. Nac. Hist. Nat. 42: 11-24.

Santelices, B. and I.A. Abbott. 1987. Geographic and marine isolation: an assessment of the marine algae of Easter Island. Pac. Sci. 41: 1-20.

Santelices, B. and I. Meneses. 2000. A reassessment of the phytogeographic characterization of temperate Pacific South America. Rev. Chil. Hist. Nat. 73: 605-614.

Santiañez, W.J.E. and K. Kogame. 2017. Transfer of Petalonia filiformis (Batters) Kuntze to the genus Planosiphon McDevit \& G.W.Saunders (Scytosiphonaceae, Phaeophyceae). Notulae algarum No. 40: 1-3.

Santiañez, W.J.E., K.M. Lee, S. Uwai, A. Kurihara, P.J.L. Geraldino, E.T. Ganzon-Fortes, S.M. Boo and K. Kogame. 2018. Untangling nets: Elucidating the diversity and phylogeny of the clathrate brown algal genus Hydroclathrus, with the description of a new genus Tronoella (Scytosiphonaceae, Phaeophyceae). Phycologia 57: 61-78.

Saunders, D.A. 1898. Phycological memoirs. Proc.Calif. Acad. Sci. Ser. 3, Bot. 1: 147-168.

Schneider, C.W., E.N. Cianciola, T.R. Popolizio, D.S. Sagnuolo, and C.E. Lane. 2015. A molecular assisted alpha taxonomic study of the genus Centroceras (Ceramiaceae, Rhodophyta) in Bermuda reveals two novel species. Algae 30: 15-33.

Schultz, N.E., C.E. Lane, L. Le Gall, D. Gey, A.R. Bigney, B. De Reviers, F. Rousseau, and C.W. Schneider. 2015. A barcode analysis of the genus Lobophora (Dictyotales, Phaeophyceae) in the western Atlantic Ocean with four novel species and the epitypification of $L$ variegate (J.V. Lamouroux) E.C. Oliveira. Eur. J. Phycol 50: 481-500.

Silva, P.C., P.W. Basson and R.L. Moe. 1996. Catalogue of the benthic marine algae of the Indian Ocean. U. Calif. Publ. Bot. 79: 1-1259.

Stamatakis, A. 2014. RAxML version 8: a tool for phylogenetic analysis and post-analysis of large phylogenies. Bioinformatics 30: 1312-1313.

Tamura, K., G. Stecher, D. Peterson, A. Filipski and S. Kumar. 2013. MEGA6: Molecular Evolutionary Genetics Analysis version 6.0. Mol. Biol. Evol. 30: 2725-2729.

Trono, G.C. Jr. 1997. Field guide and atlas of the seaweed resources of the Philippines. Bookmark, Makati City. pp. 306.

Tseng, C.K. and B.R. Lu. 1983. Two new brown algae from the Xisha Islands, South China Sea. Chin. J. Oceanol. Limn. 1: 185-189.

Vieira, C., S. D'Hondt, O. De Clerck, and C.E. Payri. 2014. Toward an inordinate fondness for stars, beetles and Lobophora? species diversity of the genus Lobophora (Dictyotales, Phaeophyceae) in New Caledonia. J. Phycol. 50: 1101-1119. 
Vieira, C., O. Camacho, M.J. Wynne, L. Mattio, R.J. Anderson, J.J. Bolton, M. Sansón, S. D’Hondt, F. Leliaert, S. Fredericq, C.E. Payri, and O. De Clerck. 2016. Shedding new light on old algae: Matching names and sequences in the brown algal genus Lobophora (Dictyotales, Phaeophyceae). Taxon 65: 689-707.

West, J.A., G.C. Zuccarello, F.F. Pedroche and S. Loiseaux de Goër. 2010. Rosenvingea orientalis (Scytosiphonaceae, Phaeophyceae) from Chiapas, Mexico: life history in culture and molecular phylogeny. Algae 25: 187-195

West, J.A., G.C. Zuccarello, E.K. Ganesan and S. Loiseaux de Goër. 2015. Investigations into lyengaria, a poorly known genus of the Scytosiphonaceae (Phaeophyceae) and description of a new species lyengaria quadriseriata. Phykos 45: 43-50.

Wynne, M.J. and J.N. Norris. 1976. The genus Colpomenia Derbès et Solier (Phaeophyta) in the Gulf of California. Smithson. Contrib. Bot. 35: 1-18.

Yaegashi, K., Y. Yamagishi, S. Uwai, T. Abe, W.J.E. Santiañez, and K. Kogame. 2015. Two species of the genus Acinetospora (Ectocarpales, Phaeophyceae) from Japan: A. filamentosa comb. nov. and $A$. asiatica sp. nov. Bot. Mar. 58: 331-343.

Yamada, Y. 1948. Marine algae. In: (Yamada, Y. and S. Kinoshita, eds.) Icones of the marine animals and plants of Hokkaido. No. 1. Hokkaido Fisheries Scientifc Institution. Yoichi, Hokkaido, Japan.

Yoshida, T. 1998. Marine algae of Japan. Uchida Rokakuho Publishing Co., Ltd., Tokyo. pp. 1222.

Supplemental Material: The online version of this article offers supplementary material (https://doi.org/10.1515/bot-2017-0089).

\section{Bionotes}

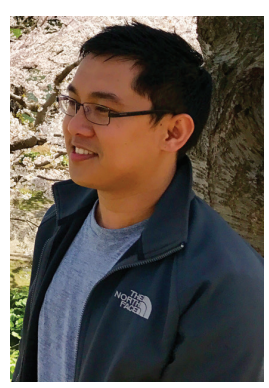

Wilfred John E. Santiañez

Department of Natural History Sciences, Graduate School of Science, Hokkaido University, Sapporo 060-0810, Japan, wjesantianez@gmail.com

Wilfred John E. Santiañez was formerly a research associate at the Marine Science Institute of the University of the Philippines where he worked on various aspects of seaweed biology, particularly seaweed diversity, ecology, and mariculture. He has a Master's degree in environment and natural resource management from the University of the Philippines Open University and is now pursuing his PhD in Hokkaido University, Sapporo, Japan. His PhD research is focused on the taxonomy and molecular phylogeny of the brown algal family Scytosiphonaceae.

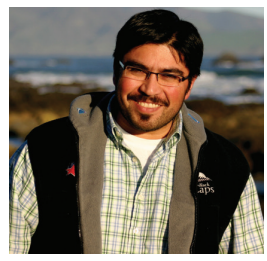

Erasmo C. Macaya

Laboratorio de Estudios Algales (ALGALAB), Departamento de Oceanografía, Casilla 160C, Universidad de Concepción, Concepción, Chile; and Millennium Nucleus: Ecology and Sustainable Management of Oceanic Island (ESMOI), Coquimbo, Chile

Erasmo C. Macaya has been an assistant professor at Concepción University, Chile since 2010. He received a primary degree in marine biology and a Master's in marine sciences from Universidad Catolica del Norte, Coquimbo, Chile. He obtained a PhD in marine biology from Victoria University, Wellington, New Zealand studying the dispersal patterns, connectivity, taxonomy and genetic diversity of the giant kelp, Macrocystis pyrifera. His research focuses on the different aspects of macroalgae, such as ecology, taxonomy and phylogeography.

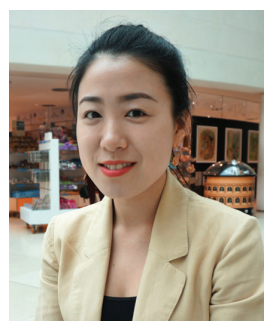

Kyung Min Lee

Department of Ecology and Genetics, University of Oulu, Oulu 90014, Finland

Kyung Min Lee earned a doctor of science in biology from Chungnam National University, Korea. Her PhD thesis focused on molecular systematics and biogeography of the brown algal family Scytosiphonaceae. In 2014, she moved to Ghent University, Belgium to study SNP discovery of Sargassum using RAD-sequencing as a postdoc for 1 year before she joined the Mutanen's lab in University of Oulu, Finland as a postdoctoral researcher in February 2015. Her current work focuses on molecular species delimitation at genomic level and clarifying issues caused by DNA barcode-sharing between species, deep intraspecific splits in DNA barcodes, and introgression on DNA-based taxonomy.

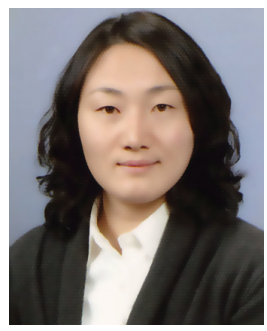

\section{Ga Youn Cho}

National Institute of Biological Resources, Incheon 22689, South Korea

Ga Youn Cho is a senior researcher in the National Institute of Biological Resources, Korea. Her research interests are biodiversity, phylogeography, taxonomy, and phylogeny of seaweeds. 


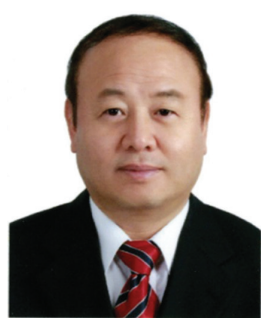

\section{Sung Min Boo}

Department of Biology, Chungnam National University, Daejeon 305-764, South Korea

Sung Min Boo is a professor emeritus at Chungnam National University. He was awarded a PhD by Seoul National University for the taxonomy of the family Ceramiaceae. His research includes the diversity and distribution of brown and red algae.

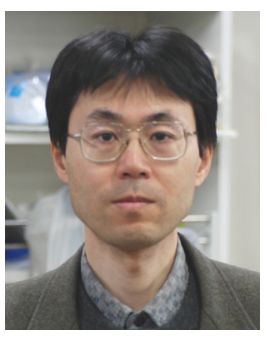

Kazuhiro Kogame

Department of Biological Sciences, Faculty of Science, Hokkaido University, Sapporo

060-0810, Japan

Kazuhiro Kogame is a Professor in the Faculty of Science, Hokkaido University, Japan. His research interests include taxonomy, phylogeny and life history of seaweeds. 


\section{Graphical abstract}

Wilfred John E. Santiañez, Erasmo C. Macaya, Kyung Min Lee, Ga Youn Cho, Sung Min Boo and Kazuhiro Kogame Taxonomic reassessment of the IndoPacific Scytosiphonaceae (Phaeophyceae): Hydroclathrus rapanuii sp. nov. and Chnoospora minima from Easter Island, with proposal of Dactylosiphon gen. nov. and Pseudochnoospora gen. nov.

https://doi.org/10.1515/bot-2017-0089 Botanica Marina 2018; x(x): xxx-xxx
Research article: A new Hydroclathrus species, $H$. rapanuii, is described from Easter Island; although not found in the island, we additionally proposed the recognition of two new genera, Dactylosiphon and Pseudochnoospora, based on three-gene phylogeny and known morphologies/ anatomies.

Keywords: Dactylosiphon gen. nov.; Easter Island; Indo-Pacific Ocean; Pseudochnoospora gen. nov.; Scytosiphonaceae.

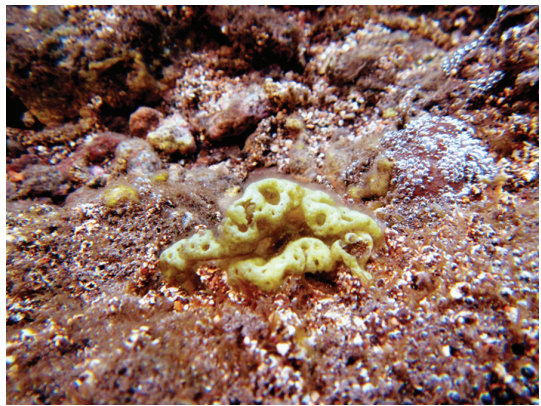

